Article

\title{
The DPSIR Framework and a Pressure-Oriented Water Quality Monitoring Approach to Ecological River Restoration
}

\author{
Xingqiang Song * and Björn Frostell \\ Division of Industrial Ecology, KTH Royal Institute of Technology, Teknikringen 34, \\ SE-100 44 Stockholm, Sweden; E-Mail: frostell@kth.se \\ * Author to whom correspondence should be addressed; E-Mail: xsong@kth.se; \\ Tel.: +46-8-790-8705; Fax: +46-8-790-5034.
}

Received: 4 July 2012; in revised form: 25 August 2012 / Accepted: 4 September 2012/

Published: 14 September 2012

\begin{abstract}
Without monitoring anthropogenic pressures on the water environment, it is difficult to set realistic river restoration targets in relation to water quality. Therefore a more holistic approach is needed to systematically explore the links between socio-economic drivers and observed water quality-related impacts on river ecosystems. Using the DPSIR (Drivers-Pressures-State of the Environment-Impacts-Responses) framework, this study linked ecological river restoration with the socio-economic sector, with the focus on promoting a pressure-oriented water quality monitoring system. Based on the European Water Framework Directive (WFD) and relevant literature, it was found that most water quality-related indicators employed today are state/impacts-oriented, while very few are pressure-oriented. As a response, we call for more attention to a DPR (Drivers-Pressures-Responses) framework in developing an industrial ecology-based pressure-oriented water quality monitoring system for aiding ecological river restoration planning. This approach is characterized in general by accounting for material-related flows throughout the socio-economic sector in relation to river ecosystem degradation. Then the obtained information would help decision makers take appropriate measures to alleviate various significant human-induced wastes and emissions at their sources. We believe that such a pressure-oriented monitoring system will substantially complement traditional state/impacts-oriented environmental and ecological monitoring and help develop more proactive planning and decision-making processes for specific river restoration projects and general water quality management.
\end{abstract}


Keywords: DPSIR; DPR; industrial ecology; monitoring; river restoration; water quality

\section{Introduction}

In recent decades, river ecosystems have been greatly impaired in many regions worldwide, partly owing to water quality degradation. Since the 1990 s, ecological river restoration has gradually become a promising way to recover impaired river systems in terms of ecosystem structure and functions [1]. In general, ecological restoration is defined as "an intentional activity that initiates or accelerates the recovery of an ecosystem with respect to its health, integrity and sustainability" [2]. In specific terms, river restoration is intended to "assist the establishment of improved hydrologic, geomorphic, and ecological processes in a degraded watershed system and replace lost, damaged, or compromised elements of the natural system", with the focus on addressing causes of system degradation [3]. To do this, river restoration planning and efforts must target the main contributing factors [4] that have exerted the most significant pressures and impacts on river ecosystems. Very often, water quality degradation is strongly addressed in river restoration projects. For example, water quality improvement is a top priority of three goal categories of river restoration projects in the United States of America [5].

In order to generate a clear picture of alternative evidence-based river restoration activities, a rigorous assessment of the current state of the system under study is essential [6]. However, it has proven to be surprisingly difficult to define a degraded, damaged or destroyed state in a scientifically unambiguous manner to aid in setting clear goals for the desired state [7]. This also holds true when addressing various perspectives from a variety of related disciplines such as hydrology, ecology and geology. Not surprisingly, one common cause of the failure of river restoration projects is the neglect of factors outside of the study area [8]. Many infrastructure-oriented projects are labeled river restoration, but are not based on water quality data or other measures of environmental impairment [9].

In river restoration, exploring the efforts of water quality monitoring to a large extent could reflect the dominant perspectives in understanding the causes of river system degradation. In this context, water quality monitoring data and indicators serve as the main basis for identifying water quality changes and pressures (stressors) in the ambient environment. In European river restoration projects, the main focuses of monitoring tend to be as follows: (i) water quality including nutrients; (ii) geomorphological changes; (iii) hydrological and hydraulic regimes; (iv) aquatic invertebrates; (v) landscape (land use patterns); and (vi) plant communities (channel and floodplain) [10]. As can be seen, water quality status currently is often determined by the use of physical, chemical and biological indicators supported by the field monitoring data. However, an understanding of biophysical causes and their corresponding impairment alone is not sufficient to maintain freshwater ecosystems and support developing sustainable water management policies [11]. In order to effectively combat and prevent contributing factors of water systems degradation, therefore, it is crucial to expand the traditional system boundaries of river restoration, taking the anthropogenic system into account.

Theoretically, the interactions between humans and the water environment can be addressed in an industrial ecology (IE) perspective [12,13]. To the best of our knowledge, the development of IE-based pressure-oriented water quality monitoring approaches is seldom discussed in the literature in relation 
to river restoration and water management. From the IE perspective, emphasis should be placed equally on understanding the links among socio-economic drivers, potential pressures (e.g., material flows and emissions) and the changing state of, and actual impacts on, a river system. Generally, IE employs a whole-system approach and seeks to understand how the ecological impacts of material flows can be minimized [14]. In the context of IE, the word "industrial" refers to all human activities occurring within the modern technological society, while the word "ecology" refers to the science of ecosystems [15]. From a principal perspective, employing the IE-based approach could aid in developing a pressure-oriented water quality monitoring system by tracing the sources of pollutants in river systems back to root causes in the socio-economic sector.

This study used the European Environment Agency's DPSIR (Drivers-Pressures-State of the Environment-Impacts-Responses) framework [16] as the basis for discussing the contemporary water quality monitoring efforts devoted to river restoration. The aim was to call for more attention to the currently neglected links between humans and the river environment in river restoration planning, with the focus on water quality monitoring systems. Furthermore, an IE-based pressure-oriented framework is suggested, aiding to develop more proactive strategies to effectively combat impaired water quality at river basin level.

\section{The DPSIR Framework and Conceptualization of Water Quality Monitoring Approaches}

\subsection{The DPSIR Framework}

As an indicator-based environmental reporting approach, the DPSIR framework aims to describe environmental problems by identifying the cause-effect relationships between the environment and various anthropogenic activities in a wider socio-economic context. In terms of this framework, socio-economic development and socio-cultural forces function as drivers (D) of human activities that increase or mitigate pressures $(\mathrm{P})$ on the environment. Environmental pressures would thus change the state of the environment (S) and result in impacts (I) on human health, ecosystems and the economy. These may lead to societal responses (R) to the corresponding drivers, pressures, state of the environment or impacts via various mitigation, prevention or adaptation measures with regard to the environmental problems identified [16]. Generally speaking, the DPSIR framework comprises a systematic approach to environmental management by exploring the interdisciplinary links among socioeconomic drivers, environment-related pressures, state of the environment, impacts of environmental changes and, finally, social responses to combat environmental degradation.

Owing to its multidisciplinary systematic characteristics, the DPSIR framework has been widely used to assess and manage various environment-related problems. This can be seen from the literature, e.g., about biological invasions in Europe [17] and assessment of forest management strategies [18]. Regarding water problems, the DPSIR framework has been used for several purposes, with regard to sustainability evaluation in coastal areas [19], integrated catchment-coastal zone management [20,21], and urbanization and subsurface environmental issues [22]. Moreover, using the DPSIR framework together with other methodologies in identifying relevant pressures and impacts has been demonstrated to be a useful approach in assessing the risk of failing to meet the objectives of the European Water 
Framework Directive (WFD) [23]. As emphasized in the literature [24], it is now regarded as a widely-utilized framework in practice for monitoring and assessing environmental changes.

Despite having been frequently employed in the environmental domain, the DPSIR framework has also attracted various criticisms. Some typical criticisms of the framework include: (i) it forms a set of static indicators and cannot take into account the dynamics of the system under discussion; (ii) it provides unclear cause-effect relationships of complex environmental problems and a limited understanding of drivers for environmental changes; (iii) it suggests linear unidirectional causal chains of environmental problems; and (iv) it analyses environmental trends only by repeating the indicator reports at regular intervals $[25,26]$. On the other hand, Karageorgis et al. argue that the focus should be on the links between the nodes of DPSIR by applying specific socio-economic and natural science-based models so as to better understand the cause-effect dynamics [27]. Furthermore, Carr et al. argue that the DPSIR framework is not a model to elaborate the cause-effect relationships that lead to particular environmental challenges; rather, its original goal is to identify appropriate indicators for the measurement and evaluation of those environmental problems [28]. In the present study, the latter is adopted as a guiding principle to discuss possibilities of developing an improved water quality monitoring system by the use of more pertinent indicators in a more holistic way.

\subsection{The DPSIR-based Classification of Water Quality Monitoring Approaches}

The aforementioned DPSIR framework was employed as the basis for discussing contemporary water quality monitoring efforts in river restoration. Our starting hypothesis was that the distribution of water quality monitoring resources could be reflected by the use of main types of indicators in practice. In the present study, water quality indicators are summarized from the EU WFD and the relevant literature on river restoration.

As inferred in the DPSIR framework, two kinds of monitoring approaches could be identified, characterized by the use of pressure-oriented and state/impacts-oriented indicators, respectively (Figure 1). For the sake of simplicity, the state/impacts-oriented approach can be said to deal with the thematic words "State", "Impacts" and "Responses" in the DPSIR framework, while the pressure-oriented approach mainly addresses "Drivers", "Pressures" and corresponding "Responses".

From a principal perspective, both state/impacts-oriented and pressure-oriented water quality monitoring approaches are essential to better understanding water quality status and disturbance in the planning process of ecological river restoration projects. Generally speaking, the state/impacts-oriented approach focuses on monitoring the water environmental state and observing various effects of water environmental degradation. Correspondingly, the state/impacts-related responses usually seek to regulate pollutants discharged into the ambient water environment. To a large extent this approach would result in the development of end-of-pipe measures, such as building more wastewater treatment facilities.

In contrast, the pressure-oriented approach intends to trace the sources of various pressures on the water environment exerted by the socio-economic activities. From an IE point of view, the goal of the pressure-oriented approach is to systematically trace stocks and flows of various wastes and emissions, especially those with the potentially highest contribution to water quality degradation. So employing this approach could contribute to reduce wastes and emissions production in the first place so as to avoid some expensive end-of-pipe remedial measures for alleviating water environmental degradation. 
This is crucial for analyzing risks of water quality degradation in a large scale of river restoration projects, including those aiming at restoring run-dry river reaches.

Figure 1. The pressure-oriented and state/impacts-oriented water quality monitoring approaches based on the DPSIR framework (the dashed red arrow shows the emphasized shortcut to effectively respond to water environmental degradation in the present study).

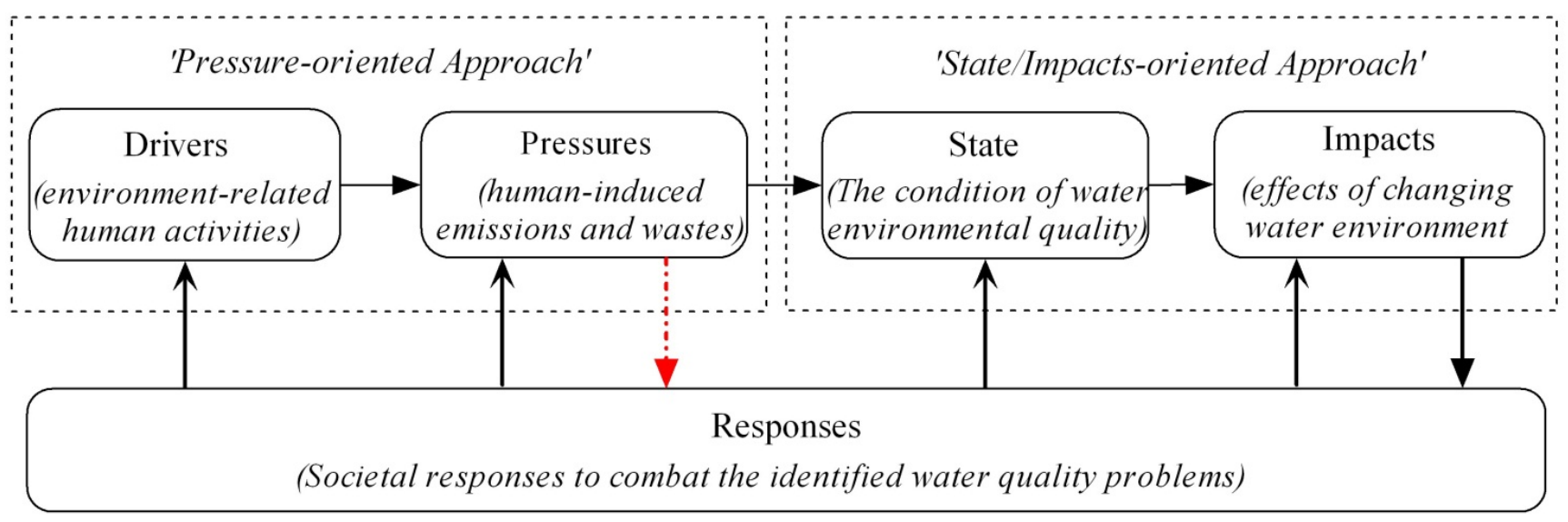

\section{Dilemmas of the Current Water Quality Monitoring System}

As aforementioned, the current water quality-related indicators and parameters in use are classified by use of the DPSIR framework, particularly those employed in the EU WFD and the relevant literature about river restoration. However, a complete review of river restoration monitoring techniques is beyond the scope of the study. Here, Table 1 presents a summary of quality elements used for the classification of ecological status of all surface waters in the EU WFD and for designing monitoring techniques for river restoration projects. This summary intends to briefly explore the current resources allocation in river restoration projects and general water quality management.

Table 1. DPSIR-based classification of monitoring techniques for river restoration $[29,30]$.

\begin{tabular}{llll}
\hline Category & Subcategory & \multicolumn{1}{c}{ Parameters/indicators } & Classification \\
\hline \multirow{2}{*}{ Hydro-morphological } & Hydrological & $\begin{array}{l}\text { Water flows (quantity \& dynamics), connection } \\
\text { to groundwater bodies, residence time, } \\
\text { hydrological budget, etc. }\end{array}$ & $\begin{array}{l}\text { Pressure-oriented } \\
\text { \& state-oriented }\end{array}$ \\
\cline { 2 - 4 } & Morphological & $\begin{array}{l}\text { River bed (structure \& substrate), channel } \\
\text { patterns, river continuity, riparian zone structure, } \\
\text { bank condition, etc. }\end{array}$ & State-oriented \\
\hline \multirow{2}{*}{ Chemical } & Water quality & $\begin{array}{l}\text { Thermal conditions, salinity, acidification status, } \\
\text { nutrients status, etc. }\end{array}$ & State-oriented \\
\hline \multirow{2}{*}{ Ecological } & Physical & $\begin{array}{l}\text { River habitat survey, riparian corridor survey, } \\
\text { meso-habitat composition, etc. }\end{array}$ & Impacts-oriented \\
\cline { 2 - 4 } & habitat & $\begin{array}{l}\text { Invertebrate fauna, phytobenthos, phytoplankton, } \\
\text { macroalgae, macrophytes, fish, etc. }\end{array}$ & Impacts-oriented \\
\hline
\end{tabular}

In accordance with the EU WFD, monitoring programmes for the assessment of surface water status, groundwater status and protected areas (Article 8) should be established within each river basin 
district. In particular, monitoring programmes for surface water should cover the ecological and chemical status and ecological potential, while those for groundwater should cover the chemical and quantitative status. In the WFD, three types of monitoring (Annex V) are suggested: (i) surveillance monitoring - routine monitoring to aid in evaluating water status, designing future programmes, and assessing long-term changes due to natural and human activities; (ii) operational monitoring - target waters probably falling below their designed status usually in the short term, which may influence the direction of the programme of measures; and (iii) investigative monitoring - for waters at risk in problems areas with pollution incidence, which would lead to response measures [31]. In the domain of river restoration, most monitoring schemes are likely to be of use only for investigative monitoring [30].

As can be seen from Table 1, most of the current concerns for water management and river restoration are state/impacts-oriented, while only water flow monitoring is partly pressure-oriented. Such state/impacts-oriented water quality monitoring information alone often fails to reflect significant pressures of water quality degradation exerted by anthropogenic activities in a holistic way. In the current domain of water management, there is much knowledge on assessing risks of water quality degradation, such as based on observed/monitored pollutants in receiving waters and hydrological changes. To a large extent, however, the anthropogenic metabolism currently is a "black box" for water managers and practitioners of river restoration. Moreover, the results of the present study also indicate a dilemma in river restoration: most river restoration monitoring efforts per se are state/impacts-oriented, while rather few are pressure-oriented (Figure 1).

\section{Moving from the State/Impacts-Oriented to a Pressure-Oriented Approach}

\subsection{Necessity of Moving towards a Pressure-Oriented Water Quality Monitoring Approach}

The aforementioned dilemma may reflect the dominant working domain of river restoration nowadays, which is mainly from the perspectives of ecologists, hydrologists and geomorphologists. The current focus of river restoration is mainly on aquatic and terrestrial ecosystems with relation to species, habitat, landscapes, ecosystem services, sediment management, water flows and allocation, and so on [32,33]. Not surprisingly, a large amount of the scarce resources in river restoration projects have been (re-) allocated for state/impacts-oriented monitoring \& modelling to meet different demands for information to assist in identifying problems and providing alternative measures.

It has been argued that river restoration should emphasize the importance of understanding driving processes when identifying priorities and setting realistic goals [34,35]. Moreover, it is of paramount importance that resources should be targeted where they will produce the most beneficial impact on river restoration projects [30]. When discussing the frequently employed approaches to develop ecological restoration strategies, King and Hobbs concluded that "the structural approach tends to focus upon mechanical manipulations of components of ecosystem structure, whereas the functional approach instead attempts to manipulate the interactions and dynamics - the ecological processes - which have been degraded" [36]. Clearly both the structural and functional approaches are coincident with the goals of striving to achieve healthy river systems. Here, two principal questions remain: (i) how to ensure acceptable water quality and thus contribute towards more successful outcomes of ecological river restoration by means of effectively dealing with both point and non-point pollutants due to 
socio-economic development; and (ii) what kinds of information could better aid in assessing the risks of water quality decline, especially when water quality monitoring data are lacking owing to dried-up river beds.

Environmental changes and the pressures that cause them can only be properly understood when they are discussed in the context of the human activities or driving forces that give rise to them [37]. Regarding water quality degradation, the current inadequate pressure-oriented monitoring efforts on river restoration may lead to less effective and efficient measures to combat river ecosystem degradation in the long term. In practice, water quality degradation is mainly caused by increased substance and element fluxes (both point and non-point) from the anthroposphere to the environment. A typical example is increased nutrient outflows in the vicinity of large urban areas often leading to various water pollution problems such as eutrophication.

In recent years, the development of water quality accounting methods has received more attention since the first attempt presented in the United Nation's Handbook of National Accounting-Integrated Environmental and Economic Accounting 2003 (SEEA-2003) [38]. In 2007, the United Nations Statistics Division (UNSD) prepared another report titled "Systems of Environmental-Economic Accounting for Water" (SEEAW), including the development of approaches to water quality accounts. In the SEEAW report, water quality accounting only refers to state and impacts, without further specifying the causes of water quality changes in an accounting period, due to difficulties in linking water quality changes to their causes [39].

In Europe, several efforts have been made to address water problems using a pressure-oriented approach. In the EU WFD [40], for example, several categories of pressure on the water environment are emphasized, including pollution pressures from diffuse and point sources, quantitative resource pressures, hydromorphological pressures and biological pressures. Another example is the Helsinki Commission (HELCOM) Baltic Sea Action Plan (BSAP), adopted in 2007, aiming to restore good ecological status of the Baltic Marine Environment by 2021. One goal of the HELCOM BSAP is to have a Baltic Sea unaffected by eutrophication by means of cutting the nutrient (phosphorous and nitrogen) load from waterborne and airborne inputs [41]. From the perspective of industrial ecologists, the HELCOM approach is of a semi-pressure oriented approach with the main focus on mapping the sources of emissions. On the other hand, however, the HELCOM BSAP has shown some early seeds to an explicit pressure-oriented approach to water management.

In order to better understand river water quality degradation, a more holistic approach is needed to clarify the interlinks between the human-oriented and the river-oriented systems with respect to water quality changes. The lack of metabolism-based pressure-oriented water quality monitoring leads to difficulties in setting water quality restoration objectives in a scientifically sound way. Those difficulties become much more obvious when planning to restore river reaches running dry for years on a large scale. Therefore, it is of crucial importance to develop more holistic strategies in water quality monitoring for river restoration within extended system boundaries, including both natural river ecosystems and the human-oriented system.

Here, we argue that pressure-oriented water quality monitoring is urgently needed to aid in developing much more proactive planning and decision-making processes for ecological river restoration and general water quality management. To some extent, the current state/impacts-oriented monitoring approach seems unable to provide adequate pertinent information to planners and decision makers on 
risks of human activity on water quality that is essential to maintain ecological functions of a river system. In other words, river restoration demands an improved water quality monitoring system so as to comprehensively combat multiple causes of water quality impairment.

\subsection{An IE-based Conceptual Approach to Aid in Accounting for Water Quality Pressures}

Besides state/impacts-oriented water quality monitoring, a DPR (Drivers-Pressures-Responses) framework (Figure 1) should be promoted in order to develop more pressure-oriented monitoring systems and thus improve water quality management. In the socio-technical system, for example, the suggested DPR framework can be exemplified by systematically tracing pollutant flows in soil, air and water due to material use, and thereafter identifying their potential water quality-related pressures on the natural river system. The point is to understand production mechanism of all emissions due to socio-economic activities and their impacts on the water environment.

The basic premise of such metabolism-based water quality pressure analysis is that the amount of resource flow into the economy determines the amount of all outputs to the environment, including wastes and emissions [42]. In particular, it is necessary to systematically trace pollutant fluxes between the socio-economic system and river water systems, including the processes of raw materials extraction, manufacturing, product delivery, product use and disposal. Such pressure-oriented monitoring could contribute to achieving a more holistic understanding of the causes of water quality-related ecosystem degradation. Together with state/impacts-oriented monitoring, the development of pressure-oriented water quality monitoring could substantially contribute to moving towards more proactive planning processes for specific river restoration projects and general water management.

Figure 2 shows our preliminary conceptual approach to aid in monitoring and accounting human-induced water quality pressures at the river basin level. In this conceptual framework, both a natural water system and a human-oriented water system are included in order to achieve a more holistic picture of the driving forces of and corresponding pressures on water quality status changes. This framework has dual aims: (i) to account materials use and pollutant fluxes in the socio-economic sector; and (ii) to interpret pressures of various society-induced emissions and wastes on the water environment.

From the perspective of IE, a pressure-oriented water quality monitoring and accounting would theoretically (and later in practice) be achieved by the use of Material Flow Analysis (MFA) and environmental Input-Output Analysis (IOA) over agreed system boundaries. MFA is a systematic assessment of the flows and stocks of materials within a spatial or temporal system boundary by connecting the sources, the pathways, and the intermediate and final sinks of materials [43]. Environmental IOA aims to enforce consistency among (inter-) industry production, pollution generation and abatement activities in the economic-ecological context [44]. Finally, the inventory results of emissions/wastes could be aggregated and assigned to impact categories, based on which the significant potential water quality pressures and their sources could be determined.

The main contribution of the suggested approach is to aid in accounting for material flows in the socio-economic system (the entire mechanism) and in generating inventories of all corresponding emissions to air, land and water in river ecosystems. Analyses of material flows should include all relevant socio-economic sectors, e.g., agricultural, industrial, energy production, mining, household, transportation, waste collection and disposal, etc. Carrying out a full MFA study is very challenging, 
considering its interdisciplinary characteristics and data requirements. However, it is rather necessary in order to obtain a more holistic picture of potential environmental pressures exerted by the socio-economic activities within a specific boundary. Once the material flows are quantified, the next step (even more challenging) is to classify and discuss both the potential and practical impacts of various emissions on water quality in the ambient water environment.

Figure 2. A conceptual approach to aid in accounting the potential anthropogenic pressures on water quality from an industrial ecology perspective.

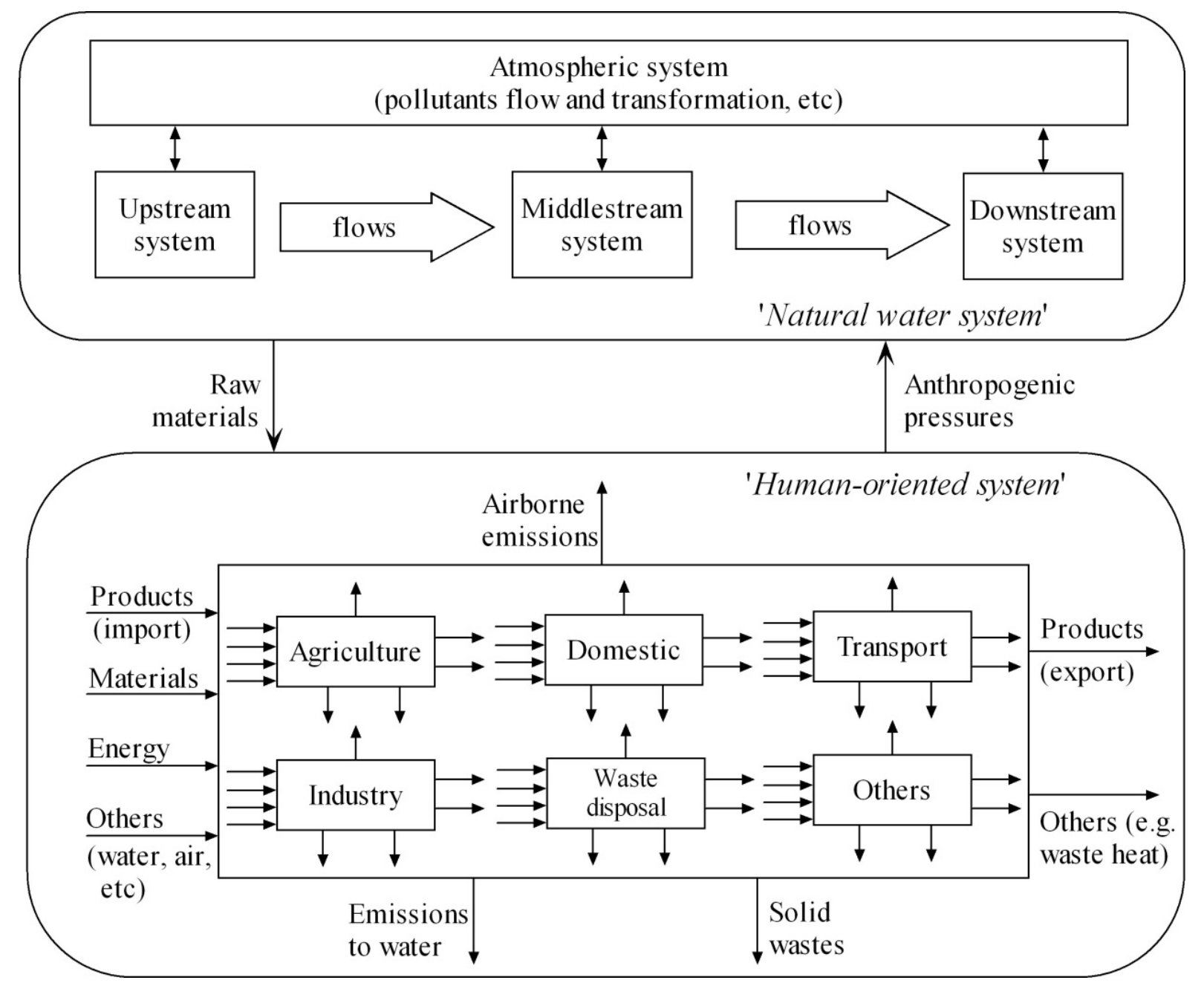

In order to develop a pressure-oriented water quality monitoring system over agreed system boundaries, close cooperation and interdisciplinary dialogues are needed among water managers, river restoration practitioners, ecologists, hydrologists, industry ecologists and experts from other relevant disciplines. The system boundary could be administrative regions, a river basin according to the EU WFD, or a combined administrative region and a river basin. Besides, decision makers are one of the key stakeholders in developing a pressure-oriented monitoring system in practice. This is partly because an effective and efficient pressure-oriented water quality monitoring system is not easy to achieve unless comprehensive documentation (data sources) is available on stocks and flows of material, water and energy through and within the socio-economic sector. 


\section{Conclusions}

This study investigated the dilemmas in water quality monitoring approaches to river restoration, focusing on the relative distribution of state/impacts-oriented and pressure-oriented efforts. Based on the DPSIR framework, the findings of the study show that the current monitoring and environmental communication system for river restoration still significantly lacks a pressure-oriented approach to better understand the root causes of water quality degradation taking the socio-economic system into account. This finding is supported by the current status of indicators use in the relevant literature. This dilemma makes it very difficult for the practitioners of river restoration and decision makers to grasp and understand performance of the whole system (the entire metabolism) in relation to pollutants emitted to a river basin by means of air transport, water transport and direct human release and/or dumping. In this regard, extensive investigations and discussions are needed on whether to introduce a hydrological system boundary approach for water quality pressure monitoring such as in the European Water Framework Directive or an administrative approach (with administrative system boundaries).

On the basis of our arguments, we call for the use of a DPR (Driver-Pressure-Responses) framework to help develop a pressure-oriented water quality monitoring system. This is crucial to improve the understanding and management of human-induced pressures on water systems and to develop more proactive strategies and realistic objective systems for water management. This call will hopefully make researchers and water managers (re-)pay more attention to understand water quality degradation pressures exerted by socio-economic activities so as to optimize resource allocation for moving towards sustainable water systems in society at large.

While the present study only suggests a preliminary conceptual approach to account for the potential pressures of material flows and emissions between society and the environment, further studies are necessary to link socio-economic drivers and pressures together with observed environmental states and impacts by collecting and generating more scientific evidence. In particular, the following thematic research issues are worth emphasizing: (i) selection of system boundaries for pressure accounting, (ii) cost-effectiveness analysis of the suggested pressure-oriented approach, and (iii) synthesis research on metabolic accounting and the use of pressure-oriented monitoring as a decision support for water management.

\section{References}

1. Aronson, J.; van Andel, J. Challenges for ecological theory. In Restoration Ecology: The New Frontier; van Andel, J., Aronson, J., Eds.; Blackwell Publishing: Oxford, UK, 2006; pp. 223-233.

2. Society for Ecologoical Restoration International (SER). The SER International Primer on Ecological Restoration; SER International Science \& Policy Working Group: Tucson, AZ, USA, 2004.

3. Wohl, E.; Angermeier, P.L.; Bledsoe, B.; Kondolf, G.M.; MacDonnell, L.; Merritt, D.M.; Palmer, M.A.; Poff, N.L.; Tarboton, D. River restoration. Water Resour. Res. 2005, 41, W10301:1-W10301:12.

4. Palmer, M.A.; Menninger, H.L.; Bernhardt, E. River restoration, habitat heterogeneity and biodiversity: A failure of theory or practice? Freshw. Biol. 2010, 55, 205-222. 
5. Bernhardt, E.; Sudduth, E.; Palmer, M.; Allan, J.; Meyer, J.; Alexander, G.; Follastad-Shah, J.; Hassett, B.; Jenkinson, R.; Lave, R. Restoring rivers one reach at a time: Results from a survey of US river restoration practitioners. Restor. Ecol. 2007, 15, 482-493.

6. Hobbs, R.; Harris, J. Restoration ecology: Repairing the Earth's ecosystems in the new millennium. Restor. Ecol. 2001, 9, 239-246.

7. Halle, S. Present state and future perspectives of restoration ecology-Introduction. Restor. Ecol. 2007, 15, 304-306.

8. Roni, P.; Hanson, K.; Beechie, T. Global review of the physical and biological effectiveness of stream habitat rehabilitation techniques. North Am. J. Fish. Manag. 2008, 28, 856-890.

9. Palmer, M.; Allan, J.D.; Meyer, J.; Bernhardt, E.S. River restoration in the twenty-first century: Data and experiential knowledge to inform future efforts. Restor. Ecol. 2007, 15, 472-481.

10. Newson, M.D.; Clark, M.J. Uncertainty and the sustainable management of restored rivers. In River Restoration: Managing the Uncertainty in Restoring Physical Habitat; Darby, S., Sear, D., Eds.; Wiley: Chichester, UK, 2008; pp. 229-250.

11. Hart, D.D.; Calhoun, A.J.K. Rethinking the role of ecological research in the sustainable management of freshwater ecosystems. Freshw. Biol. 2010, 55, 258-269.

12. Ayres, R.U.; Ayres, L.W. A Handbook of Industrial Ecology; Edward Elgar: Cheltenham, UK, 2002.

13. Boehme, S.E.; Panero, M.A.; Muñoz, G.R.; Powers, C.W.; Valle, S.N. Collaborative problem solving using an industrial ecology approach. J. Ind. Ecol. 2009, 13, 811-829.

14. Green, K.; Randles, S. Industrial Ecology and Spaces of Innovation; Edward Elgar: Cheltenham, UK, 2006.

15. Erkman, S.; Ramaswamy, R. Industrial ecology: An introduction. In Industrial Ecology and Spaces of Innovation; Green, K., Randles, S., Eds.; Edward Elgar: Cheltenham, UK, 2006; pp. 28-42.

16. Smeets, E.; Weterings, R. Environmental Indicators: Typology and Overview; European Environment Agency: Copenhagen, Denmark, 1999.

17. Hulme, P.E. Biological invasions in Europe: Drivers, pressures, states, impacts and responses. In Biodiversity under Threat; Hester, R.E., Harrison, R.M., Eds.; The Royal Society of Chemistry: Cambridge, UK, 2007; pp. 56-80.

18. Vacik, H.; Wolfslehner, B.; Seidl, R.; Lexer, M.J.; Reynolds, K.; Thomson, A.; Köhl, M.; Shannon, M.; Ray, D.; Rennolls, K. Integrating the DPSIR approach and the analytic network process for the assessment of forest management strategies. In Sustainable Forestry: From Monitoring and Modelling to Knowledge Management and Policy Science; Reynolds, K.M., Thomson, A.J., Köhl, M., Shannon, M.A., Ray, D., Rennolls, K., Eds.; CAB International: Oxfordshire, UK, 2007; pp. 393-411.

19. Bidone, E.D.; Lacerda, L.D. The use of DPSIR framework to evaluate sustainability in coastal areas. Case study: Guanabara Bay basin, Rio de Janeiro, Brazil. Reg. Environ. Chang. 2004, 4, 5-16.

20. Karageorgis, A.P.; Skourtos, M.S.; Kapsimalis, V.; Kontogianni, A.D.; Skoulikidis, N.T.; Pagou, K.; Nikolaidis, N.P.; Drakopoulou, P.; Zanou, B.; Karamanos, H.; Levkov, Z.; Anagnostou, C. An integrated approach to watershed management within the DPSIR framework: Axios River catchment and Thermaikos Gulf. Reg. Environ. Chang. 2005, 5, 138-160. 
21. Pirrone, N.; Trombino, G.; Cinnirella, S.; Algieri, A.; Bendoricchio, G.; Palmeri, L. The Driver-Pressure-State-Impact-Response (DPSIR) approach for integrated catchment-coastal zone management: Preliminary application to the Po catchment-Adriatic Sea coastal zone system. Reg. Environ. Chang. 2005, 5, 111-137.

22. Jago-on, K.A.B.; Kaneko, S.; Fujikura, R.; Fujiwara, A.; Imai, T.; Matsumoto, T.; Zhang, J.; Tanikawa, H.; Tanaka, K.; Lee, B.; Taniguchi, M. Urbanization and subsurface environmental issues: An attempt at DPSIR model application in Asian cities. Sci. Total Environ. 2009, 407, 3089-3104.

23. Borja, Á.; Galparsoro, I.; Solaun, O.; Muxika, I.; Tello, E.M.; Uriarte, A.; Valencia, V. The European Water Framework Directive and the DPSIR, a methodological approach to assess the risk of failing to achieve good ecological status. Estuar. Coast. Shelf Sci. 2006, 66, 84-96.

24. Nkonya, E.; Winslow, M.; Reed, M.S.; Mortimore, M.; Mirzabaev, A. Monitoring and assessing the influence of social, economic and policy factors on sustainable land management in drylands. Land Degrad. Dev. 2011, 22, 240-247.

25. Rekolainen, S.; Kämäri, J.; Hiltunen, M.; Saloranta, T.M. A conceptual framework for identifying the need and role of models in the implementation of the water framework directive. Int. J. River Basin Manag. 2003, 1, 347-352.

26. Svarstad, H.; Petersen, L.K.; Rothman, D.; Siepel, H.; Wätzold, F. Discursive biases of the environmental research framework DPSIR. Land Use Policy 2008, 25, 116-125.

27. Karageorgis, A.; Kapsimalis, V.; Kontogianni, A.; Skourtos, M.; Turner, K.; Salomons, W. Impact of 100-year human interventions on the Deltaic Coastal Zone of the Inner Thermaikos Gulf (Greece): A DPSIR framework analysis. Environ. Manag. 2006, 38, 304-315.

28. Carr, E.R.; Wingard, P.M.; Yorty, S.C.; Thompson, M.C.; Jensen, N.K.; Roberson, J. Applying DPSIR to sustainable development. Int. J. Sustain. Dev. World Ecol. 2007, 14, 543-555.

29. Monitoring under the Water Framework Directive; European Commission: Luxembourg, 2003.

30. England, J.; Skinner, K.S.; Carter, M.G. Monitoring, river restoration and the Water Framework Directive. Water Environ. J. 2008, 22, 227-234.

31. Chave, P.A. The EU Water Framework Directive: An Introduction; IWA Publishing: Cornwall, UK, 2001.

32. Falk, D.A.; Palmer, M.A.; Zedler, J.B. Foundations of Restoration Ecology; Island Publishing: Washington, DC, USA, 2006.

33. Adler, R.W. Restoring Colorado River Ecosystems: A Troubled Sense of Immensity, 1st ed.; Island Press: Washington, DC, USA, 2007.

34. Ehrenfeld, J.G. Defining the limits of restoration: The need for realistic goals. Restor. Ecol. 2000, $8,2-9$.

35. Beechie, T.; Pess, G.; Roni, P.; Giannico, G. Setting river restoration priorities: A review of approaches and a general protocol for identifying and prioritizing actions. North Am. J. Fish. Manag. 2008, 28, 891-905.

36. King, E.; Hobbs, R. Identifying linkages among conceptual models of ecosystem degradation and restoration: Towards an integrative framework. Restor. Ecol. 2006, 14, 369-378.

37. Europe's Environment: The Fourth Assessment; European Environment Agency: Copenhagen, Denmark, 2007. 
38. United Nations Statistics Division. Handbook of National Accounting: Integrated Environmental and Economic Accounting 2003. Available online: http://unstats.un.org/unsd/envaccounting/ seea2003.pdf (accessed on 11 September 2012).

39. United Nations Statistics Division. System of Environmental-Economic Accounting for Water (SEEAW). Available online: http://unstats.un.org/unsd/statcom/doc07/SEEAW_SC2007.pdf (accessed on 20 June 2012).

40. Common Implementation Strategy for the Water Framework Directive (2000/60/EC): Analysis of Pressures and Impacts; European Communities: Luxembourg, 2003.

41. Backer, H.; Leppänen, J.M.; Brusendorff, A.C.; Forsius, K.; Stankiewicza, M.; Mehtonen, J.; Pyhälä, M.; Laamanen, M.; Paulomäki, H.; Vlasov, N.; Haaranen, T. HELCOM Baltic Sea Action Plan-A regional programme of measures for the marine environment based on the Ecosystem Approach. Mar. Pollut. Bull. 2010, 60, 642-649.

42. Europe's Environment: The Third Assessment; European Environment Agency: Copenhagen, Denmark, 2003.

43. Brunner, P.H.; Rechberger, H. Practical Handbook of Material Flow Analysis; CRC Press: Boca Raton, FL, USA, 2003.

44. Wrisberg, N.; Udo de Haes, H. Analytical Tools for Environmental Design and Management in a Systems Perspective; Kluwer Academic Publishers: Boston, MA, USA, 2002.

(C) 2012 by the authors; licensee MDPI, Basel, Switzerland. This article is an open access article distributed under the terms and conditions of the Creative Commons Attribution license (http://creativecommons.org/licenses/by/3.0/). 